\title{
Relationship between HbA1c and capillary blood glucose self-monitoring in type 2 diabetics
}

\author{
SARA MACHADO $^{1}$, RUI MARQUES ${ }^{1}$, EDITE NASCIMENTO ${ }^{1}$, ANA MATOS $^{2,3}$, CARLA HENRIQUES $^{2,3,4}$ \\ ${ }^{1}$ Department of Internal Medicine, Tondela-Viseu Hospital Center, Viseu, Portugal \\ ${ }^{2}$ School of Technology and Management, Polytechnic Institute of Viseu, Portugal \\ ${ }^{3}$ Centre for the Study of Education, Technologies and Health, Viseu, Portugal (CI\&DETS) \\ ${ }^{4}$ Centre for Mathematics, University of Coimbra, Portugal (CMUC)
}

\begin{abstract}
Introduction. Diabetes Control and Complications Trial has established the importance of glycemic control in reducing the progression of retinopathy, nephropathy, and neuropathy in type 1 diabetics. There is little literature linking the frequency of glycemic monitoring with glycated hemoglobin A (HbA1c) in type 2 diabetics. The objectives were to assess the influence of glycemic self-monitoring on $\mathrm{HbAlc}$ in three groups of patients with type 2 diabetes (with insulin, with oral antidiabetics and with combination therapy).

Methods. The glucometer capillary surveys of 117 patients were counted in the 30 days prior to the visit to the Integrated Diabetes Unit at Centro Hospitalar Tondela-Viseu. In the three groups considered, sociodemographic characteristics (age, gender, area of residence, household and schooling) were evaluated and compared.

Results. There was no statistically significant association between $\mathrm{HbA1c}$ and the frequency of capillary glucose in any of the groups. In the evaluation of sociodemographic data, contrary to what was expected, the area of residence and schooling did not influence the value of $\mathrm{HbAlc}$.

Conclusion. These results question the role of glycemic monitoring in the metabolic control of type 2 diabetics, highlighting the need to implement therapeutic education programs so that these patients can adequately intervene in the therapeutic adjustment as a function of the information obtained by capillary glycemia.
\end{abstract}

Key words: Diabetes Mellitus Type 2, Glycated Hemoglobin A, Patient Monitoring, Blood Glucose Self-Monitoring, Health education.

\section{INTRODUCTION}

Following the Diabetes Control and Complications Trial [1], the importance of glycemic control in reducing the progression of retinopathy, nephropathy and diabetic neuropathy in type 1 diabetics, as well as a strong correlation between the frequency of capillary glycemic monitoring (CGM) with glycated hemoglobin A (HbAlc) in type 1 diabetics [2], was well established. The lack of perception and appreciation by diabetic patients of macro and microvascular complications remains an obstacle to ambitious glycemic control [3-6].

Capillary glycemic self-monitoring is a valuable instrument because it allows the definition of individualized controlled objectives, being essential in the therapeutic education of the person with diabetes [7].

There is little literature that relates the frequency of CGM with $\mathrm{HbAlc}$ in type 2 diabetics [8]. The studies conducted are not consensual. The Kumamoto Study has demonstrated that intensive glycemic control may delay the onset and progression of microvascular complications in Japanese type 2 diabetic patients [9]. Another study concludes that CGM should be based on individualized and motivational goals and that family support and gender do not influence the frequency of CGM or the reduction of $\mathrm{HbAlc}$ [8]. Another study [10], which compares a group of diabetics who selfmonitor capillary glycemia with another who does not, concludes that CGM is associated with better glycemic control irrespective of type of diabetes and medication. The influence of sociodemographic characteristics on glycemic control is not well defined [8], and the purpose of this study was to evaluate the influence of age, gender, area of residence, residing alone and schooling in the value of $\mathrm{HbAlc}$.

The impact of glycemic monitoring on anxiety and depression in patients initiating insulin therapy has also been studied and it has been concluded that there is no relationship between mood disorders and glycemic control [11]. Similarly, progressive aging of the population and increasing institutionalization, especially of vulnerable patients, should include adequate glycemic control with 
individualized needs that allow a balance between metabolic control and risk of hypoglycaemia [12, 13].

The aim of the study was to assess the influence of glycemic self-monitoring on $\mathrm{HbAlc}$ in three groups of patients with type 2 diabetes: treated with insulin only, treated with oral antidiabetics only and in combination therapy.

\section{MATERIALS AND METHODS}

This study obtained a favorable opinion from the Ethics Committee of the Tondela-Viseu Hospital Center and was approved by the Board of Directors. All patients were elucidated and clarified regarding the objectives of the study and their informed consent was requested.

A total of 140 patients were included and 117 questionnaires were validated for type 2 diabetic patients attending the consultations at the Diabetes Unit of the Tondela-Viseu Hospital Center. Glucometer recordings were evaluated in the month prior to the consultation. Three groups of patients were constituted according to the medication used in the treatment of diabetes: those treated exclusively with oral antidiabetics, those medicated with insulin only and those who were under combination therapy. The database "AlertConsult" and "SClinic" were consulted and the following parameters were recorded: $\mathrm{HbA} 1 \mathrm{c}$ in the last trimester, age, sex and area of residence, schooling level and household through telephone calls.

The following methodology was used: data on quantitative variables are summarized by mean and standard deviation or by median and interquartile amplitude. For qualitative variables, the collected data are summarized through counts and/or percentages. In each group studied: insulin therapy (I), oral antidiabetic therapy $(\mathrm{O})$, combination therapy $(\mathrm{I}+\mathrm{O})$, the relationship between $\mathrm{HbA} 1 \mathrm{c}$ and the number of capillary glycemia per month was analyzed using the Kendall's tau coefficients. The relationship between glycemic control and sociodemographic characteristics was also investigated in each group. The Mann-Whitney test and the Kruskal-Wallis test were used when the sociodemographic variable was qualitative, defining two or more groups, and the correlation coefficient was used when the variable was quantitative.

Multivariate analysis was conducted to investigate the relation between $\mathrm{HbAlc}$ and the number of capillary glycemia per month while controlling for possible confounders. Logistic regression modelling with $\mathrm{HbA} 1 \mathrm{c}$ less or more than
$7 \%$ as dependent variable was performed. The number of capillary glycemia per month, gender, age, schooling and treatment group were considered to include the model as independent variables. Interaction terms to assess possible different effects of the number of capillary glycemia per month on each treatment group were also considered. Nonsignificant variables were removed from the model.

A value of $p<0.05$ was considered statistically significant. All statistical analysis was carried out using SPSS ${ }^{\circledR}$ statistical software.

\section{RESULTS}

The sample of type 2 diabetic patients studied is composed of 3 groups depending on the medication used for the antidiabetic treatment: those medicated exclusively with oral antidiabetics (O), those medicated with insulin alone (I) and those under combination therapy $(\mathrm{I}+\mathrm{O})$.

The mean age in the total sample is $62 \pm 12$ years, the female: male ratio is $1: 1.2(45.3 \%$ vs. $54.7 \%), 75.9 \%$ of the patients lived in rural $v s$. $24.1 \%$ in urban areas, $95.7 \%$ did not live alone, and in terms of schooling only $33.3 \%$ of patients had completed secondary schooling. These sociodemographic data are summarized in Table 1.

Table 2 characterizes the sample for the three patient groups in terms of $\mathrm{HbAlc}$, number of monthly capillary glycemia and age. There is statistical evidence that the group of users taking oral antidiabetic drugs has lower $\mathrm{HbAlc}$, than both insulintreated patients and patients treated with both therapies (Figure 1). There is no significant difference between groups regarding age. The number of monthly capillary glucose is significantly higher in the insulin-treated group, followed by the $\mathrm{I}+\mathrm{O}$ group and the group medicated with oral antidiabetics alone (Figure 2).

The correlation between the number of monthly capillary glycemia and the $\mathrm{HbA} 1 \mathrm{c}$ value was not statistically significant in any of the treatment groups (Kendall's tau $=0.043, p=0.751$ for group I; Kendall's tau $=0.255, \mathrm{p}=0.062$ for $\mathrm{O}$ group; Kendall's tau $=-0.122, \mathrm{p}=0.17$ for $\mathrm{I}+\mathrm{O}$ group).

Figure 3 illustrates the weak association observed between the two variables under study (HbA1c and number of glycemia/month). It should be noted that the correlation between HbAlc and the number of blood glycemias/month in the general sample is also not significant $(\mathrm{r}=0.088$, $\mathrm{p}=0.347)$. 
Table 1

Characterization of the sample by sociodemographic data and division by treatment groups

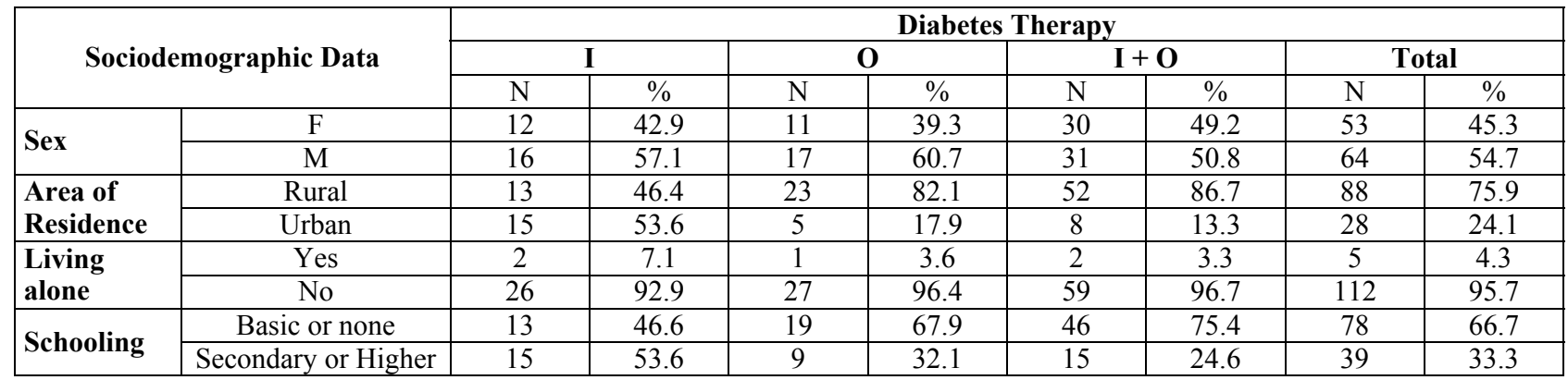

$\mathrm{I}$ - insulin, $\mathrm{O}$ - oral antidiabetic agents; $\mathrm{I}+\mathrm{O}$ - Insulin and oral antidiabetics; $\mathrm{F}$ - feminine; $\mathrm{M}$ - masculine

Table 2

Characterization of the sample for the values of HbA1c, number of monthly capillary glycemia and age, and comparison between treatment groups

\begin{tabular}{|c|c|c|c|c|c|c|}
\hline & & \multicolumn{5}{|c|}{ Diabetes Therapy } \\
\hline & & I & $\mathbf{O}$ & $\mathbf{I}+\mathbf{O}$ & Total & $\begin{array}{c}p \text { (Kruskal- } \\
\text { Wallis) }\end{array}$ \\
\hline \multirow{5}{*}{ HbA1c } & Mean & 8.3 & 7.2 & 8.2 & 8.0 & \multirow{5}{*}{0.01} \\
\hline & Median & 8.2 & 7.1 & 7.8 & 7.7 & \\
\hline & $25^{\text {th }}$ Percentile & 7.1 & 6.3 & 7.0 & 6.9 & \\
\hline & $75^{\text {th }}$ Percentile & 9.1 & 8.2 & 9.0 & 8.8 & \\
\hline & Standard deviation & 1.5 & 1.5 & 1.6 & 1.6 & \\
\hline \multirow{5}{*}{$\begin{array}{l}\text { Number of capillary } \\
\text { glycemia/month }\end{array}$} & Mean & 69 & 24 & 48 & 47 & \multirow{5}{*}{$<0.0005$} \\
\hline & Median & 62 & 19 & 47 & 40 & \\
\hline & $25^{\text {th }}$ Percentile & 46 & 9 & 29 & 26 & \\
\hline & $75^{\text {th }}$ Percentile & 86 & 32 & 59 & 62 & \\
\hline & Standard deviation & 33 & 21 & 28 & 32 & \\
\hline \multirow{5}{*}{ Age } & Mean & 61 & 63 & 62 & 62 & \multirow{5}{*}{0.70} \\
\hline & Median & 66 & 67 & 63 & 65 & \\
\hline & $25^{\text {th }}$ Percentile & 48 & 60 & 55 & 54 & \\
\hline & $75^{\text {th }}$ Percentile & 72 & 72 & 70 & 71 & \\
\hline & Standard deviation & 15 & 12 & 11 & 12 & \\
\hline
\end{tabular}

$\mathrm{I}$ - insulin, $\mathrm{O}$ - oral antidiabetic agents; $\mathrm{I}+\mathrm{O}$ - Insulin and oral antidiabetics.

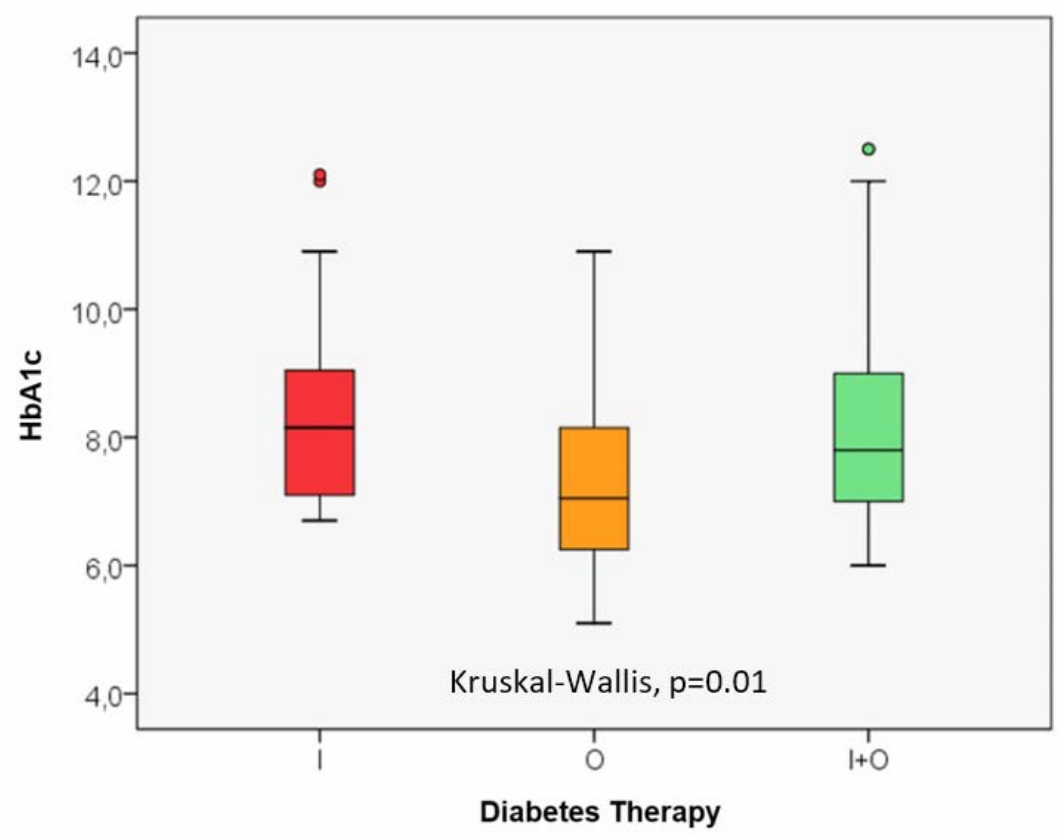

Figure 1. Distribution of HbA1c by treatment groups (box plots). I - insulin,

$\mathrm{O}-$ oral antidiabetic agents; $\mathrm{I}+\mathrm{O}-$ Insulin and oral antidiabetics. 


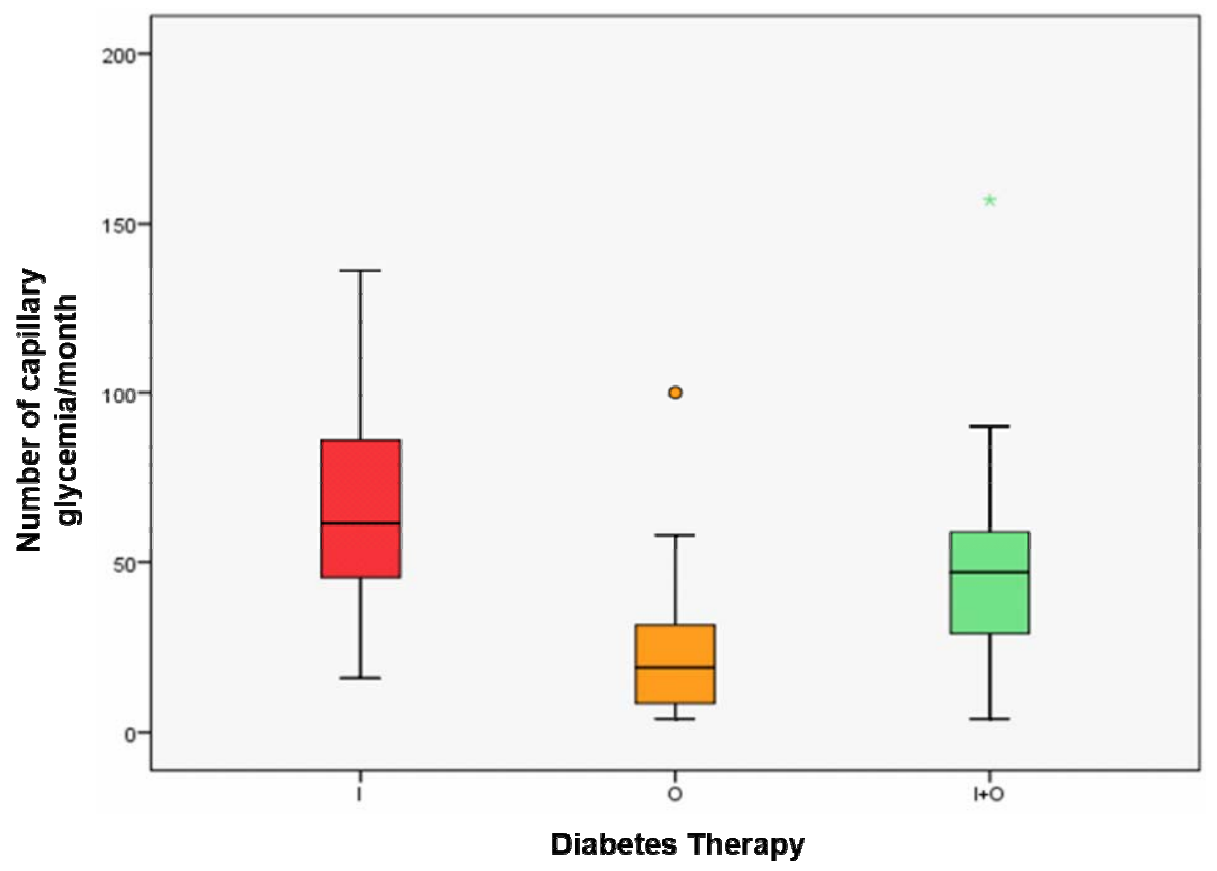

Figure 2. Distribution of the number of monthly glycemias per treatment groups (box plots). I - insulin, $\mathrm{O}$ - oral antidiabetic agents; $\mathrm{I}+\mathrm{O}-$ Insulin and oral antidiabetics. In all pairwise comparisons, with Bonferroni test, $\mathrm{p}$-value $<0.0005$.

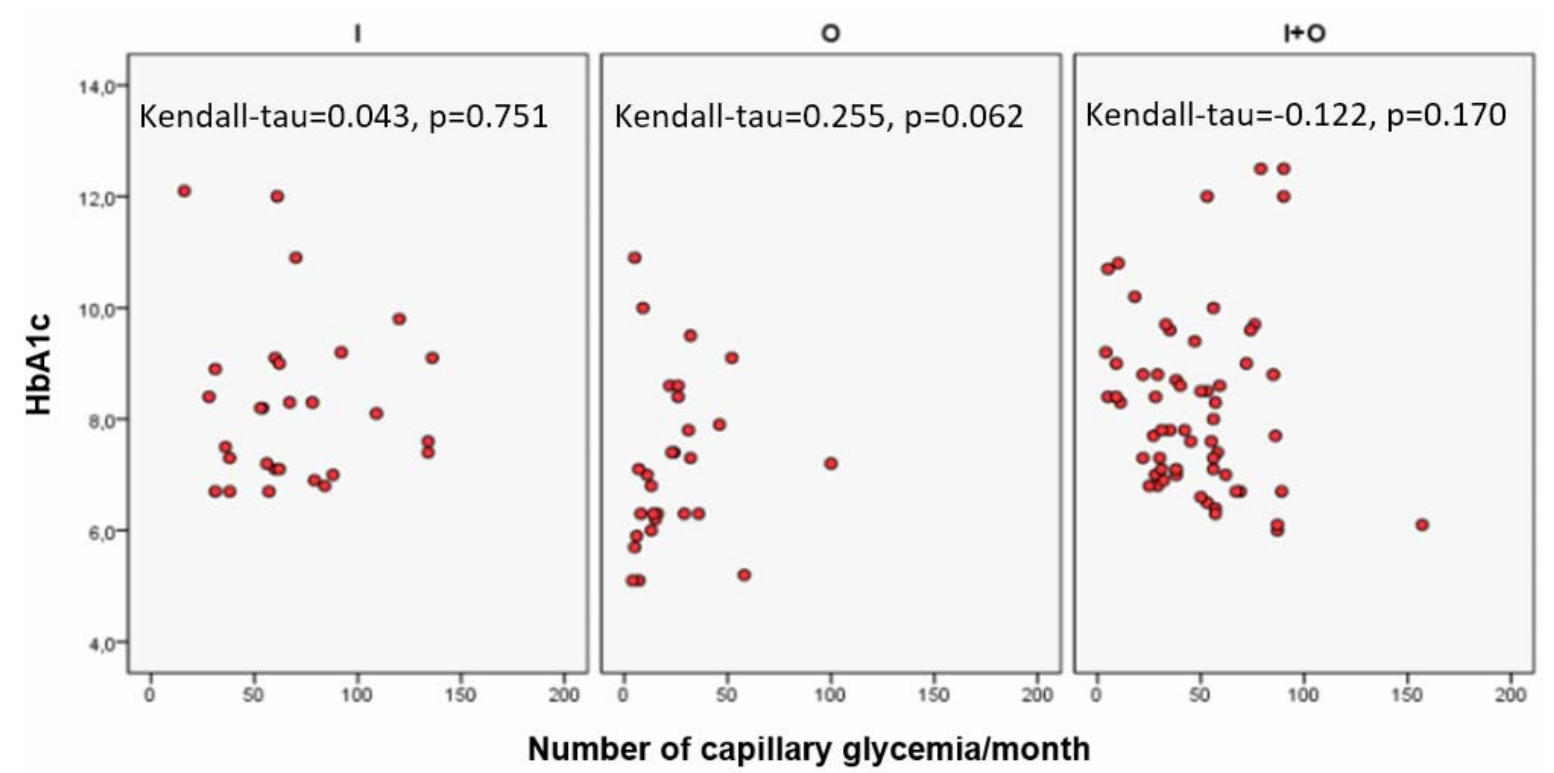

Figure 3. Association between $\mathrm{HbA1c}$ and number of monthly glycemias per treatment groups. I - insulin, $\mathrm{O}$ - oral antidiabetic agents; $\mathrm{I}+\mathrm{O}-$ Insulin and oral antidiabetics.

Since there was no relationship between the two variables for any of the groups, another approach was attempted. The patients were divided into two groups: those with $\mathrm{HbA} 1 \mathrm{c} \leq 7 \%$ and those with $\mathrm{HbA} 1 \mathrm{c}>7 \%$ to try to find out if there was a significant association with glycemic control in any of the study groups.

In the group with combined therapy $(\mathrm{I}+\mathrm{O})$ there was a marginally significant trend towards higher blood glucose self-monitoring frequency in patients with $\mathrm{HbA} 1 \mathrm{c} \leq 7 \%$, compared to patients with $\mathrm{HbAl} \mathrm{c}>7 \%$ ( $\mathrm{p}$ value for Mann- Whitney = $0.085)$. On the contrary, in the $\mathrm{O}$ group, patients with $\mathrm{HbA} 1 \mathrm{c}<7 \%$ tend to have lower CGM ( $\mathrm{p}=$ $0.05)$.

Regarding the influence of sociodemographic characteristics on glycemic control, the followings were determined:

\section{1) Age}

For each group there were no significant correlations between age and $\mathrm{HbAlc}(\mathrm{r}=0.072$, 
$p=0.716$ in group $\mathrm{I}, \mathrm{r}=0.268, \mathrm{p}=0.166$ in group $\mathrm{O}$, $\mathrm{r}=0.051 \mathrm{p}=0.694$ in group $\mathrm{I}+\mathrm{O})$. Thus, it is not possible to infer that age has some relation with glycemic control.

2) Sex

In the group treated with combination therapy there was a significant trend towards higher values of HbAlc in males $(p=0.023)$. In the remaining groups, HbA1c levels were not significantly different in males and females $(\mathrm{p}=0.909$ and $\mathrm{p}=$ 0.023 ) - Figure 4.

3) Area of residence

There was no relationship between the type of area of residence (rural or urban) and $\mathrm{HbAlc}$ values in any of the groups.

4) Living alone

Of the total number of patients in the sample few live alone (total of 5 patients), so it was not possible to perform correlation tests.

5) Schooling
There was a need to aggregate the data into two groups for statistical analysis: level of education until Basic education in one group and Secondary or Higher education in another group. It should be noted that there were 2 illiterate patients treated with insulin and 4 illiterate patients under combined therapy. There was no statistically significant association between schooling and glycemic control in any of the study groups.

Multivariate logistic regression was used to estimate the odds of a patient being uncontrolled (HbAlc $\geq 7 \%)$ adjusting for gender, schooling and age (Table 3 ). The odds of belonging to the uncontrolled group $(\mathrm{HbA} 1 \mathrm{c} \geq 7 \%)$ are lower for the patients taking $\mathrm{O}$ medication, and also for the $\mathrm{I}+\mathrm{O}$ group patients, compared with the I group patients. Furthermore, for the group of patients taking $\mathrm{I}+\mathrm{O}$ medication, the odds of being an uncontrolled patient $(\mathrm{HbA} 1 \mathrm{c} \geq 7 \%)$ decrease with the increase of the number of capillary glycemia per month (Table 3 ).

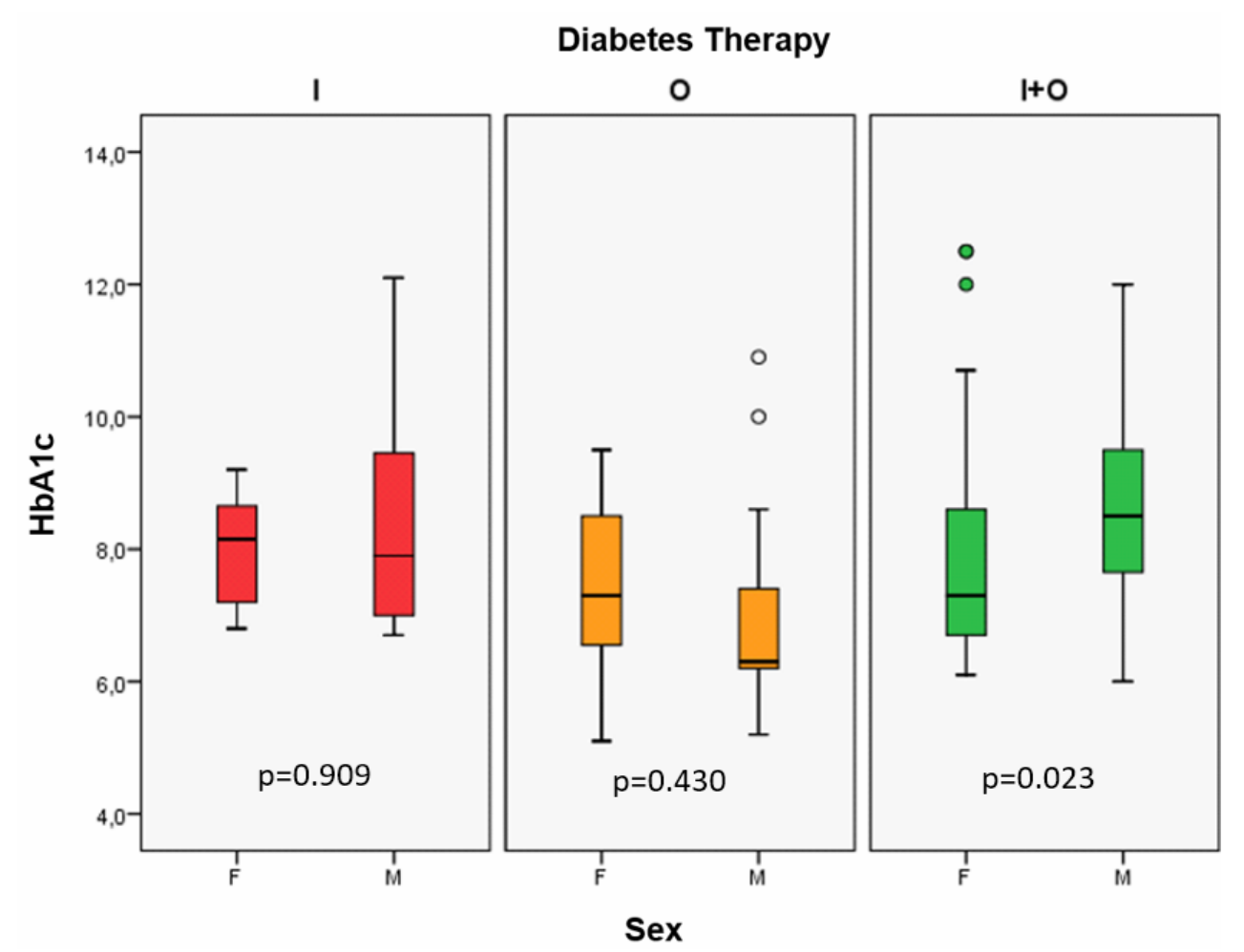

Figure 4. Association between HbAlc and sex by treatment groups. Mann-Whitney test's p-values. I - insulin, $\mathrm{O}-$ oral antidiabetic agents; $\mathrm{I}+\mathrm{O}-$ Insulin and oral antidiabetics.

Table 3

Multivariate logistic regression analysis (dependent variable $=$ risk of uncontrolled diabetes $=\mathrm{HbA} 1 \mathrm{c} \geq 7 \%$ ). Model adjusted for gender, schooling and age

\begin{tabular}{|l|c|c|c|c|}
\cline { 2 - 5 } \multicolumn{1}{c|}{} & Coef. & Exp (coef) OR & $p$ & 95\% CI \\
\hline $\begin{array}{l}\text { Interaction term: diabetes therapy }=\mathrm{I}+\mathrm{O} * \text { number of capillary } \\
\text { glycemia/month }\end{array}$ & -0.014 & 0.986 & 0.076 & $0.971-1.001$ \\
\hline Diabetes therapy = O (compared to I) & -1.644 & 0.193 & 0.003 & $0.065-0.575$ \\
\hline
\end{tabular}

OR: odds ratio; CI: confidence interval. 


\section{DISCUSSION}

A recent Italian study of 13,331 type 2 diabetic patients showed that CGM is underused in this type of patients treated with insulin or not [14]. In all treatment groups investigated, postprandial glycemia was rarely investigated, poor metabolic controls with hyper or hypoglycemia rates were warranted, and the authors concluded that CGM in type 2 diabetics in the real world needs an urgent improvement [14].

The results of our study, although representing a small sample, support that there is no association between the frequency of self-monitoring of capillary glycemia and $\mathrm{HbA} 1 \mathrm{c}$ in any of the three groups of patients studied. The strongest correlation was found in the group treated with oral antidiabetics alone, but even this is not statistically significant. It should be noted that the correlation observed in groups $\mathrm{I}$ and $\mathrm{O}$ is positive, that is, in the samples of these two groups, there was a slight tendency towards higher values of $\mathrm{HbAlc}$ in individuals with more blood glucose per month.

There are authors who argue that CGM in non-insulin treated type 2 diabetics should not be systematically recommended, concluded through the results of a meta-analysis in which evidence showed that at 6 months there was a reduction of only $0.25 \%$ in $\mathrm{HbAlc}$ in this group of patients, interpreted as having no clinical significance either in terms of glycemic control or hypoglycemia [15]. In addition, the use of CGM is associated with enormous costs, which should be better redirected to effective health improvement strategies for this category of patients [16].

In the group of patients medicated with insulin, a slight tendency of higher HbAlc was observed in patients with a greater number of monthly capillary glycemia performed. However, for the group of patients taking $\mathrm{I}+\mathrm{O}$ medication, the odds of being an uncontrolled patient $(\mathrm{HbAlc} \geq$ $7 \%$ ) decrease with the increase of the number of capillary glycemia per month. This result may represent, on the one hand, a group of patients with more severe and more difficult metabolic control. Of the three groups studied, the group treated with insulin had the worst level of metabolic control (HbAlc 8.3\%) compared to the group receiving oral antidiabetic drugs that had the best control (HbAlc 7.2\%). The high incidence of patients in the Diabetes Unit with micro and macrovascular complications, multiple comorbidities and very difficult metabolic control is a possible explanation of these differences. This group of patients is mostly medicated with insulin. On the other hand, patients receiving oral antidiabetic drugs are preferentially referred after discharge to primary care.

These data are worthy of reflection: capillary glycemia alone did not show any reflection at the level of HbA1c. Thus, it is implied that in patients with type 2 diabetes, especially insulin-treated patients due to more difficult control of the disease, we must implement measures of therapeutic education in order to enable patients to act on the information provided by glycemic control. So maybe then the results would be different.

CGM may be an important guide to consider in a personalized way in type 2 diabetics, insulintreated or not, and in particular in patients with the following characteristics: with high levels of postprandial glucose, lack of motivation and adherence, risk of not acknowledging hypoglycaemia, obese type 2 diabetic patients with oral hypoglycaemic agents and initiation of insulin therapy, patients with coronary artery disease, nephropathy, and the elderly [17].

We can consider that there is an inertia of action of type 2 diabetic patients in the adjustment of insulin doses towards uncontrolled values of glycemia. Unlike type 1 diabetic patients, in type 2 diabetics a higher number of glycemic evaluations does not reflect better glycemic control. One of the possible explanations is the need to approximate the therapeutic education level of type 1 to type 2 diabetics, implying a greater rigor and autonomy in glycemic control.

CGM leads to better glycemic control only in the context of appropriate education, both for patients and health care professionals, on how to respond to readings in terms of lifestyle and treatment adjustment [18]. Asking the patient to perform a greater number of capillary glycemic controls, without being able to act towards the values, can be counterproductive and even associated with noncompliance and withdrawal of therapy.

Individualized therapy always associated with a structured program of therapeutic education will be instrumental in improving metabolic control, because the use of CGM has been associated with possible feelings of guilt, failure, and deception when the readings are not discussed and integrated into a plan in conjunction with the doctor [19].

Consulting the publication "Diabetes Facts and Figures 2015" [20], the last one relative to our country, it shows that the cost of test strips that year was 52.6 million euros, which corresponds to $19 \%$ of the total costs of diabetes in Portugal. Type 2 diabetes accounts for about $90 \%$ of diabetic patients identified consuming a large portion of these resources. If better metabolic control cannot 
be achieved, it is imperative to question the real benefit of these costs. Thus, it seems essential for us to have a therapeutic education program that allows us to value the information obtained and to transform self-monitoring into true self-control.

Regarding the area of residence this also had no influence on the level of HbAlc. The recent improvement in accessibility may justify this. One of the data from the study that was expected with curiosity was to assess whether residing alone was associated with an upper $\mathrm{HbAlc}$ in each of the groups. The results showed that although in an inner part of the country, the number of patients residing alone is very small (five), which corresponds to only $4.2 \%$ of the sample. There is a social concern on the part of patients and their families not to reside alone.

Schooling as presumed is low $(67 \%$ have basic or lower education), however, there is no difference in glycemic control as expected [21, 22]. There is thus a compensation made in therapeutic education that counteracts the difference in schooling of these patient groups. The lowest literacy is associated with a higher prevalence of diabetes, however, in this group of patients the level of control is independent of their literacy level. This may correspond to an effort on the part of the Diabetes Unit to overcome this barrier of inequality or to reflect that what we ask of the users is accessible to all.

The recent DIAMOND study [23] evaluated the effect of continuous glycemic monitoring in real time versus self-monitoring of capillary glycemia in glycemic control in insulin-treated type 2 diabetic adults with elevated levels of $\mathrm{HbAlc}$, concluding that continuous monitoring was superior to self-monitoring of capillary glycemia, resulting in a greater decrease in $\mathrm{HbA} 1 \mathrm{c}$ level, with similar benefits observed by age group, educational levels and numeracy capacity of participants. This may be a future solution in particular in type 2 diabetic patients in need of insulin therapy.

\section{CONCLUSION}

The review of the literature in this area made it clear that more studies are needed, and that the use of ambulatory self-monitoring of capillary glycemia in type 2 diabetics has an uncertain efficiency [24].

The results of our study, as well as other observational studies and meta-analyses, point to the continued need for a long-term randomized controlled trial, mainly to evaluate the cost-effectiveness of the capillary glycemic self-monitoring test. For such studies to be effective it will be necessary to ensure that patients are able to monitor and appropriately modify behaviors in response to CGM readings. We may be unambitious in our goals for true self-control of people with type 2 diabetes. Self-monitoring of capillary glycemia by our patients is not enough. We have to evolve into a therapeutic education program that transforms self-monitoring into self-control, and thus obtain better metabolic control so that capillary glycemia research is much more than "finger pricking".

Declaration of interest: The authors declare that there are not conflicts of interest.

Introducere. Controlul glicemic asupra reducerii progresiei retinopatiei, nefropatiei si neuropatiei în diabetul zaharat de tip 1 este cunoscut datorită studiului clinic Diabetes Control and Complications Trial. In literatură sunt puține date ce asociază frecvența monitorizării glicemice cu nivelul hemoglobinei glicozilate (HbAlc) la pacientii cu diabet zaharat tip 2. Obiectivele acestui studiu au fost de a evalua influența automonitorizării Hb1 Ac in 3 grupe de pacienți cu diabet tip 2 (cu tratament cu insulină, cu antidiabetice orale sau cu combinația celor două).

Materiale şi metode. Analizele glucometrelor a 117 pacienți au fost luate în considerare cu 30 de zile înaintea vizitei la Spitalul Tondela-Viseu, Portugalia. În cele trei grupuri considerate au fost înregistrate caracteristicile sociodemografice (gen, vârstă, mediul de proveniență, nivel educațional).

Rezultate. $N u$ au fost găsite diferențe semnificative statistic intre frecvența monitorizării glicemiei capilare şi HbAlc. Contrar aşteptărilor mediul de proveniență şi nivelul educațional nu au influențat valoarea HbAlc.

Concluzii. Aceste rezultate evidențiază necesitatea implementării programelor educaționale astfel încât acești pacienți să poată interveni adecvat în ajustarea terapiei medicamentoase bazându-se pe datele obținute la măsurarea glucozei capilare. 
Correspondence to: Sara Machado, M.D, Department of Internal Medicine,

Tondela-Viseu Hospital Center, Viseu, Portugal, Phone: 00351910952495

E-mail: sarabranmac@gmail.com

\section{REFERENCES}

1. NATHAN DM. The diabetes control and complications trial/epidemiology of diabetes interventions and complications study at 30 years: Overview. Diabetes Care. 2014;37(1):9-16.

2. MILLER KM, BECK RW, BERGENSTAL RM, GOLAND RS, HALLER MJ, MCGILL JB, et al. Evidence of a strong association between frequency of self-monitoring of blood glucose and hemoglobin Alc levels in T1D exchange clinic registry participants. Diabetes Care. 2013;36(7):2009-14.

3. STRAIN WD, COS X, HIRST M, VENCIO S, MOHAN V, VOKÓ Z, et al. Time to do more: Addressing clinical inertia in the management of type 2 diabetes mellitus. Diabetes Res Clin Pract. 2014;105(3):302-12.

4. SNOEK F. Barriers to good glycaemic control: the patient's perspective. Int J Obes [Internet]. 2000;24:S12-20.

5. GONDER-FREDERICK LA, COX DJ, RITTERBAND LM. Diabetes and behavioral medicine: The second decade. J Consult Clin Psychol. 2002;70(3):611-25.

6. RUSHFORTH B, MCCRORIE C, GLIDEWELL L, MIDGLEY E, FOY R. Barriers to effective management of type 2 diabetes in primary care: Qualitative systematic review. Br J Gen Pract. 2016;66(643):e114-27.

7. DORSEY JL, BECKER MH, AL. E. Glycemic targets: Standards of medical care in diabetes - 2018. Diabetes Care. 2018;41(Supplement 1):S55-64.

8. BRIDGES JF, BRIGNAC D, THOMAS S, KENT C, OGBULI M, DRAPER J, et al. Optimizing HgAlC and glucose monitoring frequency in patients with Type 2 diabetes. Med Sci Monit [Internet]. 2012;18(12):CR693-7.

9. SHICHIRI M, KISHIKAWA H, OHKUBO Y WN. Long-term results of the Kumamoto study on optimal diabetes control in type 2 diabetic patients. Diabetes Care. 2000;23.

10. KHOWAJA K, WAHEED H. Original article Self-glucose monitoring and glycaemic control at a tertiary care university hospital, Karachi, Pakistan. J Pak Med Assoc. 2010 Dec;60(12):1035-8.

11. FISHER L, POLONSKY W, PARKIN CG, JELSOVSKY Z, AMSTUTZ L, WAGNER RS. The impact of blood glucose monitoring on depression and distress in insulin-nä̈ve patients with type 2 diabetes. Curr Med Res Opin [Internet]. 2011;27(sup 3): $39-46$.

12. WANG JS, LEE I TE, LEE WJ, LIN SD, SU SL, TU S TE, et al. Glycemic excursions are positively associated with changes in duration of asymptomatic hypoglycemia after treatment intensification in patients with type 2 diabetes. Diabetes Res Clin Pract [Internet]. 2016;113:108-15.

13. OSMAN O, SHERIFALI D, STOLEE P, HECKMAN G. Diabetes Management in Long-Term Care: An Exploratory Study of the Current Practices and Processes to Managing Frail Elderly Persons with Type 2 Diabetes. Can J Diabetes [Internet]. 2016;40(1):17-30.

14. ROSSI MC, LUCISANO G, CERIELLO A, MAZZUCCHELLI C, MUSACCHIO N, OZZELLO A, et al. Real-world use of self-monitoring of blood glucose in people with type 2 diabetes: an urgent need for improvement. Acta Diabetol [Internet]. 2018.

15. FARMER A. Meta-analysis: Self-monitoring in non-insulin-treated type 2 diabetes improved HbAlc by 0.25\%. Ann Intern Med. 2012;156(12):24199.

16. MALANDA UL, BOT SD, NIJPELS G. Self-monitoring of blood glucose in noninsulin-using type 2 diabetic patients: It is time to face the evidence. Diabetes Care. 2013;36(1):176-8.

17. SCHNELL O, ALAWI H, BATTELINO T, CERIELLO A, DIEM P, FELTON AM, et al. Self-monitoring of blood glucose in type 2 diabetes: Recent studies. J Diabetes Sci Technol. 2013;7(2):478-88.

18. CLAR C, BARNARD K, CUMMINS E, ROYLE P, WAUGH N. Self-monitoring of blood glucose in type 2 diabetes: Systematic review. Health Technol Assess (Rockv). 2010;14(12):1-140.

19. ROBSON J, SMITHERS H, CHOWDHURY T, BENNETT-RICHARDS P, KEENE D, DOSTAL I, et al. Reduction in selfmonitoring of blood glucose in type 2 diabetes: An observational controlled study in East London. Br $\mathrm{J}$ Gen Pract. 2015;65(633):e256-63.

20. SOCIEDADE PORTUGUESA DE DIABETOLOGIA. Diabetes: Factos e Números. Vol. 11, Relatório Anual do Observatório Nacional da Diabetes 11/2014. 2014. 0-64 p.

21. HUANG YM, SHIYANBOLA OO, CHAN HY. A path model linking health literacy, medication self-efficacy, medication adherence, and glycemic control. Patient Educ Couns [Internet]. 2018;

22. OLESEN K, F REYNHEIM AL, JOENSEN L, RIDDERSTRÅLE M, KAYSER L, MAINDAL HT, et al. Higher health literacy is associated with better glycemic control in adults with type 1 diabetes: a cohort study among 1399 Danes. BMJ Open Diabetes Res Care [Internet]. 2017;5(1):e000437.

23. BILLINGS LK, PARKIN CG, PRICE D. Baseline glycated hemoglobin values predict the magnitude of glycemic improvement in patients with type 1 and type 2 diabetes: Subgroup analyses from the DIAMOND study program. Diabetes Technol Ther [Internet]. 2018;20(8):561-5.

24. OLRY DE LABRY LIMA A, MOYA GARRIDO MN, ESPÍN BALBINO J. Systematic review of economic evaluation studies and budget impact on ambulatory monitoring of capillary glucose in type 2 diabetics. Prim Care Diabetes [Internet]. 2014;8(1):13-21.

Received September 9, 2018 